\title{
PENGUKURAN EFISIENSI DAN EKUITAS MEREK SEBAGAI REFERENSI KONSUMEN UNTUK MEMILIH MINUMAN ENERGI
}

\author{
Oleh: \\ Irmayanti Hasan*)
}

\begin{abstract}
The purpose of this research is to find out the level of relative efficiency on energy drink and the effects to the brand equity. As the analysis instrument, the writer uses an application from linear programming named as Data Envelopment Analysis (DEA) that has some advantages in measuring the level of relative efficiency for multiple input and output compared to any other methods. The next step is to discover the effects of the level of relative efficiency upon brand equity.

The writer takes seven different brands of energy drink as the sample in finding out the level of relative efficiency and 112 respondents in order to gain the value of brand equity upon those energy drinks. The result of the research reveals that there is one inefficient brand, whereas the hypothesis test shows that there is a connection between level of efficiency and element of equity (brand attractiveness, brand association, and perception quality), but the element of commercial advertisement has no effect to the efficiency. The yielded descriptive statistics shows that the inefficient brand surprisingly achieves higher value of equity than the efficient brands.

Implication from this research elucidates that there is a producer who sets a higher price in order to position the brand as the high quality product, likewise, advertisement also holds a great role in communicating a product to the public. The purpose of this research is to find out the level of relative efficiency on energy drink and the effects to the brand equity. As the analysis instrument, the writer uses an application from linear programming named as Data Envelopment Analysis (DEA) that has some advantages in measuring the level of relative efficiency for multiple input and output compared to any other methods. The next step is to discover the effects of the level of relative efficiency upon brand equity.

The writer takes seven different brands of energy drink as the sample in finding out the level of relative efficiency and 112 respondents in order to gain the value of brand equity upon those energy drinks. The result of the research reveals that there is one inefficient brand, whereas the hypothesis test shows that there is a connection between level of efficiency and element of equity (brand attractiveness, brand association, and perception quality), but the element of commercial advertisement has no effect to the efficiency. The yielded descriptive statistics shows that the inefficient brand surprisingly achieves higher value of equity than the efficient brands.

Implication from this research elucidates that there is a producer who sets a higher price in order to position the brand as the high quality product, likewise, advertisement also holds a great role in communicating a product to the public.
\end{abstract}

Key words: Efficiency, Brand Equity, Reference 


\section{PENDAHULUAN}

\section{Latar Belakang}

Perkembangan pasar minuman energi di Indonesia sekarang ini meningkat, hal ini secara tidak langsung banyak dipengaruhi oleh kesadaran masyarakat terhadap pentingnya kesehatan tubuh dan ditunjang dengan meningkatnya tarap hidup masyarakat (Indocommercial, 1998;18). Selain itu keberhasilan para produsen menciptakan image bahwa minuman tersebut dapat menambah vitalitas tubuh semakin menjadikan penjualan minuman ini terus meningkat. Fenomena ini memberikan peluang pasar yang besar dan menjanjikan bagi para produsen untuk masuk dalam jajaran industri minuman energi yang pada akhirnya akan meningkatkan persaingan.

Banyaknya perusahaan yang bergerak dibidang minuman energi mengakibatkan banyaknya pilihan bagi konsumen untuk memilih dari perusahaan dan merek mana yang akan dipilih. Dalam menentukan pilihannya konsumen tentu akan sangat terbantu bila ada informasi mengenai merek mana yang harganya efisien, dalam arti harga yang relatif lebih murah tapi mampu memberikan produk yang berkualitas sama baiknya atau lebih baik dibandingkan produk yang harganya lebih mahal. Hal ini sesuai dengan konsep Consumer Bill of Rights dari Jhon F.Kennedy (1960;67) yang menyatakan bahwa salah satu hak yang dimiliki oleh masyarakat konsumen adalah hak untuk memilih. Perwujudan dari hak tersebut adalah konsumen berhak memperoleh barang dalam tingkat harga yang sesuai (fair price) dengan tingkat kualitas yang memuaskan. Karena itu efisiensi harga merupakan salah satu sasaran penting dalam usaha perlindungan konsumen (Prederick, 1992 dalam Nugroho, 1995;89).

Disisi lain, kesedian membayar mahal untuk suatu merek tidak lain karena merek tersebut mampu menambah nilai bagi mereka. Nilai dalam konteks merek merupakan persepsi dan keyakinan atas produk yang menyebabkan konsumen ingin terasosiasikan dan membelinya. Konsumen bersedia membayar lebih tinggi suatu produk karena melekat padanya merek yang merupakan jaminan konsistensi kualitas dan nilai produk tertentu yang diyakini terkandung di dalamnya. Tanpa adanya merek konsumen menjadi kurang merasa aman dari kemungkinankemungkinan buruk di luar harapannya. Nilai yang ditambahkan oleh merek 
terhadap produk disebut ekuitas merek (brand equity) (Aaker,1991 dalam Umar, 2000;35). Besarnya ekuitas merek dikendalikan oleh citra merek (brand image) sebagai konsep referensi konsumen.

\section{Rumusan Masalah}

1. Bagaimana tingkat efisiensi relatif dari merek minuman energi?

2. Bagaimana pengaruh tingkat efisiensi relatif terhadap nilai ekuitas merek (kepedulian merek, kepedulian iklan, asosiasi merek, dan kualitas persepsi)?

\section{Tujuan Penelitian}

1. Untuk mengetahui tingkat efisiensi relatif dari merek minuman energi

2. Untuk mengetahui pengaruh tingkat efisiensi relatif terhadap nilai ekuitas merek (kepedulian merek, kepedulian iklan, asosiasi merek, dan kualitas persepsi).

\section{TINJAUAN PUSTAKA}

\section{Penelitian Terdahulu}

Nugroho (1997) dalam penelitiannya yang menggunakan analisis DEA menghasilkan bahwa mobil Timor S-515 dan Suzuki Baleno merupakan mobil yang efisien dibandingkan merek lainnya dalam katagori kelas sedan 1500-1600 cc. Walaupun begitu untuk konsep mobil Timor S-515 sebagai Mobil Nasional belum tepat. Penelitian Baskoro (2002) yang menguji hubungan antara unsurunsur bauran pemasaran dengan penciptaan ekuitas merek dan menggunakan Structural Equation Modeling (SEM) menghasilkan bahwa unsur-unsur bauran pemasaran mempunyai hubungan positif dengan dimensi ekuitas merek.

\section{Landasan Teoritis}

Efisiensi teknis merupakan efisien proses mengkonversi input menjadi output, dengan kata lain merupakan produk unit kegiatan ekonomi untuk memproduksi tingkat output maksimum dari input-input dan teknologi yang tetap. Dasar yang digunakan dalam pengukuran efisiensi teknis adalah teknologi produksi yang menurut teori, teknologi produksi dapat ditunjukkan oleh isoquant, fungsi biaya, atau fungsi keuntungan.

Untuk menganalisis efisiensi teknis umumnya digunakan alat analisis primal production fuction. Dengan menggunakan pendekatan pemprograman 
yang dipelopori oleh Parrel (1957;54) dan diregeneralisir Chanes (1988;95) dikenal sebagai Data Envelopment Analysis (DEA).

Menurut Aaker $(1991 ; 81)$ ekuitas merek merupakan seperangkat aset atau hutang yang melekat pada merek, yakni nama dan simbol, yang menambah atau mengurangi nilai suatu produk atau jasa bagi perusahaan atau pelanggannya. Komponen ekuitas merek ada 5 bagian, yakni:

1. Loyalitas merek: mencerminkan tingkat keterikatan konsumen dengan suatu merek produk.

2. Kepedulian merek: menunjukkan kesanggupan seorang calon pembeli untuk mengenali atau mengingat kembali bahwa suatu merek merupakan bagian dari katagori produk tertentu.

3. Kualitas persepsi: mencerminkan persepsi pelanggan terhadap keseluruhan kualitas atau keunggulan suatu produk atau jasa langganan berkenaan dengan maksud yang diharapkan.

4. Asosiasi merek: mencerminkan pencitraan suatu merek terhadap suatu kesan tertentu dalam kaitannya dengan kebiasaan, gaya hidup, manfaat, atribut produk, geografis, harga, pesaing, selebritis, dan lain-lain.

5. Aset merek lain, seperti simbol paten, saluran pemasaran dan sebagainya.

Adapun pengembangan dari kelima ekuitas merek tersebut di atas adalah

1. Fungsi Loyalitas Merek

Beberapa potensi yang dapat diberikan loyalitas merek kepada perusahaan:

a) Reduced marketing cost (mengurangi biaya pemasaran)

Dengan kaitannya dengan biaya pemasaran, maka lebih murah mempertahankan pelanggan dibandingkan dengan upaya untuk mendapatkan pelanggan baru. Jadi biaya pemasaran akan mengecil jika loyalitas merek meningkat. Ciri yang paling nampak dari jenis pelanggan ini adalah mereka membeli suatu produk karena harganya murah.

b) Trade leverage (meningkatkan perdagangan)

Loyalitas yang kuat terhadap suatu merek akan menghasilkan peningkatan perdagangan dan memperkuat keyakinan perantara pemasaran. Dapat disimpulkan bahwa pembeli ini dalam membeli suatu merek didasarkan atas kebiasaan mereka selama ini. 
c) Attracting new customers (menarik minat pelanggan baru)

Dengan banyaknya pelanggan suatu merek yang merasa puas dan suka pada merek tersebut akan menimbulkan perasaan yakin bagi calon pelanggan untuk mengkonsumsi merek tersebut terutama jika pembelian yang mereka lakukan mengandung resiko tinggi. Disamping itu, pelanggan yang puas umumnya akan merekomendasikan merek tersebut kepada orang yang dekat dengannya sehingga akan menarik pelanggan baru.

d) Provide time to respon to competitive threats (memberi waktu untuk merespon ancaman persaingan)

Loyalitas merek akan memberikan waktu pada sebuah perusahaan untuk merespon gerakan pesaing. Jika salah satu pesaing mengembangkan produk yang unggul, pelanggan yang loyal akan memberikan waktu pada perusahaan tersebut untuk memperbaharui produknya dengan cara menyesuaikan atau menetralisasikannya.

2. Fungsi Kepedulian merek

Penciptaan nilai oleh kepedulian merek dapat dilakukan paling sedikit dengan empat cara kepada perusahaan:

a) Anchor to which other association can be attached, artinya suatu merek dapat digambarkan seperti suatu jangkar dengan beberapa rantai. Rantai menggambarkan asosiasi dari merek tersebut.

b) Familiarity-Linking, artinya dengan mengenal merek akan menimbulkan rasa terbiasa terutama untuk produk-produk yang bersifat low involvement (keterlibatan rendah) seperti pasta gigi, kertas tisu, dan lain-lain. Suatu kebiasaan dapat menimbulkan keterkaitan kesukaan yang kadang-kadang dapat menjadi suatu pendorong dalam membuat keputusan.

c) Substance/Commitment. Kepedulian akan nama dapat menandakan keberadaan, komitmen, dan inti yang sangat penting bagi suatu perusahaan. Secara logika, suatu nama dikenal karena beberapa alasan, mungkin karena program periklanan perusahaan yang ekstensif, jaringan distribusi yang luas, eksistensi yang sudah lama dalam industri, dan lainlain. Jika kualitas dua merek sama, kepedulian merek akan menjadi faktor yang menentukan dalam keputusan pembelian konsumen. 
d) Brand to consider. Langkah pertama dalam suatu proses pembelian adalah menyeleksi dari suatu kelompok merek-merek yang dikenal untuk dipertimbangkan merek mana yang diputuskan akan dibeli. Merek yang memiliki top of mind tinggi mempunyai nilai yang tinggi. Jika suatu merek tidak tersimpan dalam ingatan, merek tersebut tidak dipertimbangkan dibenak konsumen. Biasanya merek yang disimpan dalam ingatan konsumen adalah merek yang disukai atau merek yang dibenci.

\section{Fungsi Kualitas Persepsi}

Secara umum kualitas persepsi dapat menghasilkan nilai-nilai berikut:

a) Alasan untuk membeli

Keterbatasan informasi, uang dan waktu membuat keputusan pembelian seorang pelanggan sangat dipengaruhi oleh kualitas persepsi suatu merek yang ada di benak konsumen, sehingga seringkali alasan keputusan pembeliannya hanya didasarkan kepada kualitas persepsi dari merek yang akan dibelinya.

b) Differensiasi atau posisi dan harga premium

Salah satu karakteristik penting dari merek produk adalah posisinya dalam kualitas persepsi, apakah merek tersebut merupakan yang terbaik? Atau sama baiknya dengan merek lainnya? Apakah merek tersebut ekonomis?, super optimum? Atau optimum? Salah satu keuntungan dari kualitas persepsi adalah memberikan ruang pilihan dalam menentukan harga premium (premium price). Harga premium dapat meningkatkan laba yang secara langsung dapat meningkatkan profitabilitas. Jika harga berperan sebagai pengarah kualitas maka harga premium cenderung memperkuat kualitas persepsi.

c) Perluasan saluran dis tribusi

Kualitas persepsi mempunyai arti penting bagi para pengecer, distributor, dan saluran distribusi lainnya. Para pengecer dan distributor akan termotivasi untuk menjadi penyalur produk/merek dengan kualitas persepsi yang tinggi, yang berarti dapat semakin memperluas distribusi dari merek produk tersebut. Karena citra distributor dipengaruhi oleh merek produk dan layanan yang masuk dalam jalur distribusinya. Maka menyalurkan 
produk berkualitas merupakan faktor penting. Dengan citra penyalur produk berkualitas, distributor dapat menawarkan harga-harga yang menarik untuk selanjutnya menguasai niaga distribusi. Disisi lain konsumen sangat berminat untuk membeli produk yang memiliki kualitas persepsi kuat sehingga secara umum saluran distribusi dimotivasi untuk menyalurkan merek-merek produk yang memiliki kualitas persepsi kuat.

d) Perluasan merek

Suatu merek produk dengan kualitas persepsi yang kuat dapat dieksploitasi ke arah perluasan merek. Merek dengan kualitas persepsi kuat dapat digunakan untuk memperkenalkan kategori produk baru yang beraneka ragam. Produk dengan kualitas persepsi yang kuat akan mempunyai kemungkinan sukses yang lebih besar dibandingkan dengan merek yang kualitas persepsinya lemah, sehingga perluasan produk dari merek dengan kualitas persepsi kuat memungkinkan perolehan pangsa pasar yang lebih besar lagi. Dalam hal ini kualitas persepsi merupakan jaminan yang signifikan atas perluasan-perluasan merek tersebut.

4. Fungsi Asosiasi Merek

a) Help process/retrieve information, yaitu membantu proses penyusunan informasi.

b) Differentiate (membedakan)

Suatu asosiasi dapat memberikan landasan yang penting bagi upaya pembedaan suatu merek dari merek lain.

c) Reason to buy (alasan pembelian)

Asosiasi merek membangkitkan berbagai atribut produk atau manfaat bagi konsumen (customer benefit) yang dapat memberikan alasan spesifik bagi konsumen untuk membeli dan menggunakan merek tersebut.

d) Create positive attitude/feeling (menciptakan sikap atau perasaan positif) Beberapa asosiasi mampu merangsang suatu perasaan positif yang pada gilirannya merembet ke merek yang bersangkutan. Asosiasi-asosiasi tersebut dapat menciptakan perasaan positif atas dasar pengalaman mereka sebelumnya serta pengubahan pengalaman tersebut menjadi suatu yang lain daripada yang lain. 
e) Basis for extensions (landasan untuk perluasan)

Suatu asosiasi dapat menghasilkan landasan bagi suatu perluasan dengan menciptakan rasa kesesuaian (sense of fit) antara merek dan sebuah produk baru, atau dengan menghadirkan alasan untuk membeli produk perluasan tersebut.

5. Aset-aset Merek Lainnya

Merek yang kuat dapat memberikan keuntungan bagi perusahaan untuk mendapatkan kerjasama dengan pihak-pihak terkait dalam rantai nilai perusahaan, khususnya dengan anggota-anggota sistem saluran distribusi. Pada akhirnya, merek yang kuat dapat menjadi jalur untuk membentuk, mengembangkan, dan mempertahankan keunggulan kompetitif berkelanjutan perusahaan.

Model penelitian yang digunakan mengacu pada model hierarchy of effect yang disesuaikan, hal ini digunakan untuk menggambarkan urutan proses munculnya keyakinan (belief), sikap (attitudes), dan perilaku (behavior) yang merupakan tahap pemprosesan informasi (Mowen,1990;85).

Proses pembentukan persepsi hingga menjadi ekuitas merek merupakan suatu antecedent. Pada saat ekuitas telah terbentuk maka akan muncul akibat atau konsekuensi yang disebut sebagai preferensi dan keinginan membeli. Konsekuensi inilah yang sebenarnya diharapkan oleh semua pengusaha.

Untuk mendapatkan angka ekuitas merek, penelitian ini mengacu kepada pendekatan dari Keller (1993;25) yaitu hanya menghitung komponen ekuitas merek yang bersifat perseptual saja, yakni kepedulian (terhadap merek dan iklan), asosiasi merek dan kualitas persepsi, sehingga dapat disusun hipotesis sebagai berikut:

H1: merek dengan atribut yang hampir sama namun dengan tingkat efisiensi yang relatif lebih tinggi akan menghasilkan kepedulian merek yang lebih tinggi.

$\mathrm{H} 2$ : merek dengan atribut yang hampir sama namun dengan tingkat efisiensi yang relatif lebih tinggi akan menghasilkan kepedulian iklan yang lebih tinggi.

H3: merek dengan atribut yang hampir sama namun dengan tingkat efisiensi yang relatif lebih tinggi akan menghasilkan asosiasi merek yang lebih tinggi. 
H4: merek dengan atribut yang hampir sama namun dengan tingkat efisiensi yang relatif lebih tinggi akan menghasilkan kualitas persepsi yang lebih tinggi.

\section{METODE PENELTIAN}

\section{Lokasi Penelitian}

Peneltian ini dilakukan di kota Malang yang merupakan kota pendidikan, memiliki 5 kecamatan dan 50 kelurahan serta jumlah penduduk dewasa berusia 15 tahun ke atas pada tahun 2001 menurut BPS kota Malang (2005) berjumlah 202.470 jiwa.

\section{Pendekatan Jenis Penelitian}

Pendekatan pada penelitian ini adalah pendekatan kuantitatif, sedang jenis penelitian ini adalah penelitian survei, yaitu penelitian yang mengambil sampel dari satu populasi dan menggunakan kuesioner sebagai alat pengumpulan data yang pokok (Singarimbun, 1995;5).

\section{Populasi dan Sampel}

Populasi dalam penelitian ini adalah untuk mengukur tingkat efisiensi relatif diambil berbagai merek minuman energi dan diambil sampel hanya minuman dalam kemasan botol kaca dengan ukuran $150 \mathrm{ml}$, yaitu hanya sebanyak 7 merek, sedangkan untuk mengetahui nilai ekuitas merek minuman tersebut langsung dari konsumen yang pernah mengkonsumsi minuman tersebut dengan batasan usia minimal 15 tahun, dan untuk pengambilan sampel digunakan rumus Slovin (Sevilla, dkk, 1993;35):

$$
\mathrm{n}=\frac{\mathrm{N}}{1+\mathrm{N}(\mathrm{e})^{2}}
$$

dan dihasilkan sampel minimal 100 orang.

\section{Instrumen dan Pengukuran Variabel}

\section{a. Ope rasionalisasi Efisiensi}

Pengukuran efisiensi harga di sini adalah mengenai efisiensi merek yang dapat memberikan manfaat relatif sama dengan merek lain tetapi harga lebih murah, atau mempunyai harga yang sama dengan merek lain tetapi mempunyai 
kualitas yang lebih baik, atau mempunyai harga yang relatif murah dari merek lain dan kualitasnyapun juga lebih baik.

\section{b. Ope rasionalisasi Ekuitas Merek}

Pada tahapan ini adalah melakukan verifikasi perbedaan tingkatan ekuitas merek pada masing-masing produk yang diteliti. Pengujian hipotesis satu hingga empat dilakukan dengan melihat skor jawaban komponen dua merek berpasangan. Selain itu akan dihitung nilai masing-masing dimensi ekuitas untuk mendapatkan angka ekuitas merek. Nilai ekuitas merek dalam penelitian ini hanyalah angka relatif.

\section{Teknik Analisis Data}

\section{a. Data Envelopment Analysis (DEA)}

Analisis ini bertujuan untuk mengukur tingkat efisiensi masing-masing merek minuman energi yang diteliti. Merek yang memiliki skor DEA=1 adalah efisiensi, sedangkan merek yang memiliki skor DEA $<1$ tidak efisien.

Pendekatan DEA akan memperhitungkan variabel putusan yang terdiri dari variabel input dan output. Untuk setiap kelompok merek akan disusun program linear sesuai dengan jumlah anggota merek yang akan dibandingkan. Selanjutnya data dari variabel input dan output dimasukkan ke dalam formulasi DEA (program linear) sebagai berikut:

Fungsi Tujuan: $\mathrm{n}$

Maksimumkan $\emptyset_{0}=\sum U_{\mathrm{rj}} Y_{\mathrm{rj}}$

$$
\mathrm{r}=1
$$

Fungsi batasan:

$\mathrm{n}$

$\mathrm{n}$

1. $=\sum_{\mathrm{r}=1} \mathrm{U}_{\mathrm{rj}} \mathrm{Y}_{\mathrm{rk}}-\sum_{\mathrm{r}=1} \mathrm{~V}_{\mathrm{rj}} \mathrm{X}_{\mathrm{rk}} \leq 0$

$\mathrm{n}$

2. $=\sum \mathrm{V}_{\mathrm{rj}} \mathrm{X}_{\mathrm{rj}}=1$ $\mathrm{r}=1$

3. $\mathrm{U}_{\mathrm{rj}} \mathrm{Y}_{\mathrm{rj}} \geq \dot{\varepsilon}$

$\dot{\varepsilon}=$ bil. positif kecil $>0$

dimana:

$\emptyset_{0}=$ score efisiensi relatif, $1=100 \%$

$\mathrm{U}_{\mathrm{rj}}=$ timbangan output ke $\mathrm{r}$ untuk $\mathrm{j}$ 
$\mathrm{Y}_{\mathrm{rj}}=$ jumlah output ke $\mathrm{r}$ untuk unit $\mathrm{j}$

$\mathrm{V}_{\mathrm{rj}}=$ timbangan input ke $\mathrm{r}$ untuk $\mathrm{j}$

$\mathrm{X}_{\mathrm{rj}}=$ jumlah input ke $\mathrm{r}$ untuk unit $\mathrm{j}$

$\mathrm{Y}_{\mathrm{rk}}=$ jumlah output ke $\mathrm{r}$ untuk unit $\mathrm{k}$

$\mathrm{X}_{\mathrm{rk}}=$ jumlah input ke $\mathrm{r}$ untuk unit $\mathrm{k}$

Untuk mempermudah proses perhitungan digunakan software khusus untuk pendekatan DEA yaitu dengan program Warwick.

\section{b. Wilcoxon Matched-Pairs Signed-Ranks Test}

Pengujian hipotesis satu hingga empat menggunakan pendekatan statistik non-parametrik, dalam hal ini alat analisis yang relevan adalah uji Wilcoxon. Perbedaan yang akan diukur, yakni nilai komponen ekuitas dua merek yang diberikan responden. Hal ini dilakukan dengan menghitung perbedaan nilai keempat komponen ekuitas merek antara dua merek dan memeringkat perbedaan absolutnya. Selanjutnya jika t hitung lebih kecil dari t statistiknya maka hipotesis nol ditolak.

\section{HASIL PENELITIAN}

\section{Karakteristik Responden}

Berdasarkan 112 responden yang dijadikan sampel diperoleh gambaran karakertistik responden yang terangkum pada Tabel 1.Pada Tabel 1 terlihat pada aspek jenis kelamin, responden laki-laki lebih banyak daripada responden wanita, hal ini menunjukkan bahwa laki-laki lebih banyak membeli minuman energi. Berdasarkan hasil wawancara yang dilakukan diketahui bahwa hal ini disebabkan minuman energi menggambarkan keperkasaan dan kekuatan bagi yang meminumnya. Disamping itu aktivitas yang dilakukan laki-laki lebih banyak membutuhkan tenaga dan menuntut stamina dan vitalitas yang prima.

Dari aspek usia responden, terlihat kelompok usia terbesar yang melakukan pembelian adalah usia antara 36 - 45 tahun, yaitu sebesar 42,9\%. Hal ini menggambarkan bahwa segmen pasar minuman energi adalah sebagian besar orang dewasa atau kelompok usia dalam masa produktif yang tinggi. 
Tabel 1. Karakteristik Responden

\begin{tabular}{|c|c|c|c|}
\hline No & Keterangan & Jlh & $\%$ \\
\hline 1 & $\begin{array}{l}\text { Jenis kelamin: } \\
\text { Laki-laki } \\
\text { Wanita }\end{array}$ & $\begin{array}{l}71 \\
41\end{array}$ & $\begin{array}{l}63,4 \\
36,6\end{array}$ \\
\hline 2 & $\begin{array}{l}\text { Usia (th): } \\
15-25 \\
26-35 \\
36-45 \\
45 \text { keatas }\end{array}$ & $\begin{array}{l}12 \\
37 \\
48 \\
15\end{array}$ & $\begin{array}{l}10,7 \\
33 \\
42,9 \\
13,4\end{array}$ \\
\hline 3 & $\begin{array}{l}\text { Pendidikan: } \\
\text { SD } \\
\text { SMP } \\
\text { SMA } \\
\text { Diploma } \\
\text { Sarjana }\end{array}$ & $\begin{array}{l}3 \\
5 \\
50 \\
21 \\
33\end{array}$ & $\begin{array}{l}2,7 \\
4,5 \\
44,6 \\
18,8 \\
29,4\end{array}$ \\
\hline 4 & $\begin{array}{l}\text { Pekerjaan: } \\
\text { PNS } \\
\text { Peng. Swasta } \\
\text { Wiraswasta } \\
\text { Pensiunan } \\
\text { Lain-lain }\end{array}$ & $\begin{array}{l}20 \\
41 \\
18 \\
12 \\
21\end{array}$ & $\begin{array}{l}17,8 \\
36,6 \\
16,1 \\
10,7 \\
18,8\end{array}$ \\
\hline 5 & $\begin{array}{l}\text { Pendapatan (ribuan) } \\
<250 \\
250-500 \\
501-750 \\
751-1000 \\
>1000\end{array}$ & $\begin{array}{l}7 \\
21 \\
32 \\
43 \\
9\end{array}$ & $\begin{array}{l}6,3 \\
18,8 \\
28,5 \\
38,4 \\
8\end{array}$ \\
\hline 6 & $\begin{array}{l}\text { Sumber informasi: } \\
\text { TV } \\
\text { Radio } \\
\text { Koran } \\
\text { Majalah }\end{array}$ & $\begin{array}{l}91 \\
11 \\
9 \\
1\end{array}$ & $\begin{array}{l}81,3 \\
9,8 \\
8,0 \\
0,9\end{array}$ \\
\hline
\end{tabular}

Sumber: Data primer (diolah)

Kalau dilihat dari aspek pendidikan ternyata responden terbesar adalah responden dengan tingkat pendidikan SMA dan Sarjana (44,6\% dan 29,4\%). Hal ini dapat dikatakan bahwa segmen pasar minuman energi memiliki tingkat pendidikan yang baik, artinya pasar minuman ini juga terkait dengan tingkat pendidikan yang dimiliki.

Berdasarkan jenis pekerjaan jumlah responden terbesar adalah yang bekerja sebagai Pegawai swasta dengan prosentase sebesar 36,6\%. Hal ini menunjukkan bahwa rata-rata segmen pasar minuman energi ini sudah memiliki pekerjaan yang tetap. 
Sedangkan ditinjau dari aspek pendapatan, maka kelompok terbesar adalah yang berpendapatan antara Rp 751.000,00 - Rp 1.000.000,00 yakni sebesar $38,4 \%$. Hal demikian dapat dikatakan bahwa konsumen minuman energi ini adalah mereka yang cukup baik ekonominya (penghasilannya) untuk kota Malang ukuran seperti itu dikatakan sebagai golongan ekonomi menengah.

Untuk sumber informasi iklan utama responden sebagian besar berasal dari televisi $(81,3 \%)$, radio, koran, dan majalah. Dari jawaban di atas tampak bahwa televisi memiliki status sebagai acuan utama pencarian informasi, meski responden tidak harus dalam posisi pencarian informasi aktif (active search).

Pada Tabel 1 di atas terlihat pada aspek jenis kelamin, responden laki-laki lebih banyak daripada responden wanita, hal ini menunjukkan bahwa laki-laki lebih banyak membeli minuman energi. Berdasarkan hasil wawancara yang dilakukan diketahui bahwa hal ini disebabkan minuman energi menggambarkan keperkasaan dan kekuatan bagi yang meminumnya. Disamping itu aktivitas yang dilakukan laki-laki lebih banyak membutuhkan tenaga dan menuntut stamina dan vitalitas yang prima.

Dari aspek usia responden, terlihat kelompok usia terbesar yang melakukan pembelian adalah usia antara 36 - 45 tahun, yaitu sebesar $42,9 \%$. Hal ini menggambarkan bahwa segmen pasar minuman energi adalah sebagian besar orang dewasa atau kelompok usia dalam masa produktif yang tinggi.

Kalau dilihat dari aspek pendidikan ternyata responden terbesar adalah responden dengan tingkat pendidikan SMA dan Sarjana (44,6\% dan 29,4\%). Hal ini dapat dikatakan bahwa segmen pasar minuman energi memiliki tingkat pendidikan yang baik, artinya pasar minuman ini juga terkait dengan tingkat pendidikan yang dimiliki.

Berdasarkan jenis pekerjaan jumlah responden terbesar adalah yang bekerja sebagai Pegawai swasta dengan prosentase sebesar 36,6\%. Hal ini menunjukkan bahwa rata-rata segmen pasar minuman energi ini sudah memiliki pekerjaan yang tetap.

Sedangkan ditinjau dari aspek pendapatan, maka kelompok terbesar adalah yang berpendapatan antara Rp 751.000,00 - Rp 1.000.000,00 yakni sebesar $38,4 \%$. Hal demikian dapat dikatakan bahwa konsumen minuman energi ini 
adalah mereka yang cukup baik ekonominya (penghasilannya) untuk kota Malang ukuran seperti itu dikatakan sebagai golongan ekonomi menengah.

Untuk sumber informasi iklan utama responden sebagian besar berasal dari televisi $(81,3 \%)$, radio, koran, dan majalah. Dari jawaban di atas tampak bahwa televisi memiliki status sebagai acuan utama pencarian informasi, meski responden tidak harus dalam posisi pencarian informasi aktif (active search).

\section{Analisis Efisiensi Relatif}

Ringkasan hasil analisis efisiensi relatif dari masing-masing minuman energi yang diteliti dapat dilihat pada Tabel 2 berikut:

\section{Tabel 2 Tingkat Efisiensi Relatif}

\begin{tabular}{|c|l|r|}
\hline No & \multicolumn{1}{|c|}{ Merek } & $\begin{array}{r}\text { Tingkat } \\
\text { Efisiensi }\end{array}$ \\
\hline 1. & Kratingdaeng & $88.35 \%$ \\
2. & Hemaviton & $100 \%$ \\
3. & Lipovitan H & $100 \%$ \\
4. & Lipovitan RJ & $100 \%$ \\
5. & Panther & $100 \%$ \\
6. & Fit-Up & $100 \%$ \\
7. & M-150 & $100 \%$ \\
\hline
\end{tabular}

Sumber: Data primer (diolah)

Pada Tabel 2 di atas dapat dilihat bahwa dari 7 merek minuman energi yang diteliti ada satu merek yang tidak efisien yakni Kratingdaeng $(88,35 \%)$. Selain untuk melihat tingkat efisiensi relatif analisis DEA juga memberikan informasi mengenai posisi yang tidak efisien dibandingkan rekan terdekatnya yang efisien (Peers) dalam hal ini rekan terdekat dari Kratingdaeng adalah Panther yang bisa dijadikan acuan untuk perbandingan input dan output. dimana Kratingdaeng dapat mencapai efisien kalau untuk input: harga dan output: kalsium harus sama 100\% dengan Panther.

\section{Statistik Deskriptif}

Statistik deskriptif dalam penelitian ini terfokus pada jawaban responden terhadap pertanyaan tentang komponen ekuitas merek. Ukuran kepedulian merek yang digunakan adalah unaided awareness (recall) yang diukur dalam skala 2 titik, kepedulian iklan diukur dengan frekuensi penyebutan isi iklan yang diklasifikasikan menjadi empat bagian sehingga terentang dalam skala 1 hingga 4 , berikutnya asosiasi merek dan kualitas persepsi yang diukur dengan skala 5 titik 
dengan rentang -2 hingga 2. Semua informasi analisis deskriptif terangkum dalam Tabel 3.

Tabel 3. Statistik Deskriptif

\begin{tabular}{|c|c|c|c|}
\hline Merek & Variabel & Mean & SD \\
\hline \multirow[t]{17}{*}{ Panther } & Kepedulian Merek & 0,30 & 0,46 \\
\hline & Kepedulian Iklan & 1,79 & 0,67 \\
\hline & Asosiasi Merek: & & \\
\hline & Minuman terbaik & $-0,26$ & 0,95 \\
\hline & Rasa sesuai & $-0,57$ & 1,00 \\
\hline & Tingkat kekhasan & $-0,79$ & 0,73 \\
\hline & Aroma & $-0,57$ & 0,92 \\
\hline & Manfaat & $-0,52$ & 0,89 \\
\hline & Citra & $-0,68$ & 0,91 \\
\hline & Kualitas & $-0,54$ & 0,87 \\
\hline & Reputasi prod. & $-0,69$ & 0,66 \\
\hline & Kual. Persepsi & & \\
\hline & Manfaat & $-0,52$ & 0,84 \\
\hline & Harga & $-0,54$ & 1,00 \\
\hline & Aman & $-0,12$ & 0,89 \\
\hline & Rasa & $-0,56$ & 0,96 \\
\hline & Gengsi & $-0,87$ & 0,77 \\
\hline \multirow[t]{16}{*}{ Krating daeng } & Kepedulian Merek & 0,70 & 0,46 \\
\hline & Kepedulian Iklan & 1,80 & 0,91 \\
\hline & Asosiasi Merek: & & \\
\hline & Minuman terbaik & 1,10 & 0,83 \\
\hline & Rasa sesuai & 1,01 & 0,69 \\
\hline & Tgk. Kekhasan & 0,84 & 0,78 \\
\hline & Aroma & 0,56 & 0,99 \\
\hline & Manfaat & 0,75 & 0,65 \\
\hline & Citra & 0,84 & 0,79 \\
\hline & Kualitas & 0,89 & 0,56 \\
\hline & Reputasi prod. & 0,37 & 0,76 \\
\hline & $\begin{array}{l}\text { Kual. Persepsi: } \\
\text { Manfaat }\end{array}$ & 0,95 & 0,63 \\
\hline & Harga & 0,73 & 0,76 \\
\hline & Aman & 0,71 & 0,74 \\
\hline & Rasa & 1,04 & 0,86 \\
\hline & Gengsi & 0,73 & 0,72 \\
\hline
\end{tabular}

Sumber: Data primer (diolah)

Dari Tabel 3 tersebut dapat diperoleh bahwa nilai ekuitas merek untuk Kratingdaeng lebih tinggi daripada Panther, bahkan untuk nilai asosiasi merek dan kualitas persepsi untuk semua itemnya (Panther) menunjukkan nilai negatif. Hal ini menunjukkan bahwa merek Kratingdaeng di mata konsumen lebih baik imagenya daripada merek Panther. 


\section{Pengujian Hipotesis}

Berdasarkan hasil statistik dengan menggunakan uji Wilcoxon diperoleh hasil bahwa hipotesis satu, tiga, dan empat yang menyatakan bahwa merek dengan atribut yang hampir sama namun dengan tingkat efisiensi yang re latif lebih tinggi akan menghasilkan kepedulian merek, asosiasi merek dan kualitas persepsi yang lebih tinggi adalah diterima. Hal ini dilihat karena nilai signifikansi asimtosi menunjukkan angka yang lebih kecil $(0,000)$ dari nilai $\alpha(0,05)$. Sedangkan untuk hipotesis kedua yang menyatakan bahwa merek dengan atribut yang hampir sama namun dengan tingkat efisiensi relatif lebih tinggi akan menghasilkan kepedulian iklan yang lebih tinggi, hal ini ditolak karena nilai signifikansi asimtosis menunjukkan angka lebih besar $(0,898)$ dari nilai $\alpha(0,05)$. Ringkasan analisis Wilcoxon dapat dilihat pada Tabel 4 berikut:

Tabel 4 Ringkasan Analisis Wilcoxon

\begin{tabular}{|l|l|l|l|}
\hline \multicolumn{1}{|c|}{ Variabel } & Nilai Z & $\begin{array}{c}\text { Pro } \\
\text { b. }\end{array}$ & \multicolumn{1}{|c|}{ Keterangan } \\
\hline 1.Kepedulian Merek & $-4,158$ & .000 & Signifikan \\
2.Kepedulian Iklan & $-0,128$ & .898 & Tidak Signifikan \\
& & & Signifikan \\
3.Asosiasi Merek & & .000 & Signifikan \\
Minuman terbaik & $-8,055$ & .000 & Signifikan \\
Rasa sesuai selera & $-8,360$ & .000 & Signifikan \\
Tingkat kekhasan & $-8,797$ & .000 & Signifikan \\
Aroma & $-7,150$ & .000 & Signifikan \\
Manfaat & $-7,939$ & .000 & Signifikan \\
Citra & $-8,108$ & .000 & Signifan \\
Kualitas & $-8,266$ & .000 & Signifikan \\
Reputasi produsen & $-7,496$ & .000 & \\
4.Kualitas Persepsi & & & Signifikan \\
Manfaat & $-8,598$ & .000 & Signifikan \\
Harga & $-7,350$ & .000 & Signifikan \\
Aman & $-5,842$ & .000 & Signifikan \\
Rasa & $-8,367$ & .000 & Signifikan \\
Gengsi & $-8,896$ & .000 & \\
\hline
\end{tabular}

Sumber: Data primer (d iolah)

\section{Pembahasan}

Melihat dari hasil penelitian sepertinya ada pertentangan antara teori dan kenyataan. Dari hasil analisis DEA terbukti yang paling tidak efisien adalah merek Kratingdaeng dan yang efisien adalah merek Panther, sedangkan menurut hasil statistik deskriftif justru Kratingdaeng sebagai merek yang tidak efisien 
mendapatkan nilai ekuitas yang tinggi karena terlihat bahwa Kratingdaeng lebih dikenal dan disukai konsumen.

Hal seperti ini menurut penulis bisa saja terjadi, karena efisiensi secara teori berbeda dengan teori menurut persepsi konsumen. Seperti halnya merek Kratingdaeng secara teori tidak efisien karena harganya paling mahal walaupun kandungan yang ada hampir Sama dengan merek Panther, tetapi persepsi konsumen menyatakan bahwa biarpun harga mahal tetapi bisa memuaskan kebutuhan mereka itu dianggap efisien. Jadi image yang diciptakan oleh Kratingdaeng bahwa harga mahal akan menunjukkan kualitas yang baik sudah tertanam dalam benak konsumen. Walaupun sebenarnya hal tersebut belum tentu selalu benar. Hal ini sesuai dengan pendapat Dodds (1991;25) yang menyatakan bahwa harga digunakan sebagai alat positioning utama untuk membedakan suatu produk. Ekuitas merek bisa turun apabila konsumen secara kuat menghubungkan harga dengan kualitas produk dan menggunakannya sebagai indikator kualitas.

Selain itu ada beberapa hal yang menyebabkan terjadinya harga yang tidak efisien (Nugroho, 1995;74). Struktur pasar yang bersifat monopoli maupun oligopoli. Dalam struktur pasar ini karena jumlah penjual hanya satu atau kalaupun lebih dari satu, tetapi jumlahnya hanya sedikit akan mengakibatkan kurangnya tingkat persaingan. Dengan demikian penjual bisa menetapkan harga yang tinggi untuk meraih keuntungan besar. Adanya strategi harga mahal yang bisa berupa prestige pricing, yaitu harga yang memang ditentukan mahal dan ditunjukkan untuk menjaring konsumen yang beranggapan bahwa harga mahal mencerminkan kualitas yang tinggi, atau berupa skimming pricing, yaitu harga yang mahal pada awal peluncuran suatu produk baru dan diturunkan pada saat pesaing mulai banyak yang masuk (Tjiptono, 1998). Bahkan menurut Kotler (1998;63) terdapat beberapa strategi harga yang merugikan konsumen, yaitu strategi harga mahal yang memberikan kualitas produk tingkat menengah tapi harganya tinggi, strategi ekonomis palsu yang memberikan harga menengah tetapi kualitas produk rendah, dan strategi penipuan yang memberikan harga tinggi tapi kualitas produk rendah.

Kalau mengacu pada teori hirarki efek, maka penelitian ini juga membuktikan bahwa pengetahuan konsumen yang cukup banyak dan lama 
tertanam dalam ranah kognisinya akan berubah menjadi suatu belief, setelah melalui proses pengaitan antara atribut dan manfaat yang berasal dari informasi eksternal termasuk iklan. Pada saat yang sama iklan dapat memunculkan respon afektif berupa sikap atau persepsi yang mengarahkan seseorang untuk berprilaku tertentu. Respon afektif ini menurut penulis cukup dimanfaatkan oleh Kratingdaeng melalui iklan di TV, di mana perusahaan pandai mengeksploitasikan kesan mewah dan menggunakan artis ternama dalam format yang sangat menarik dan bervariasi.

\section{Implikasi Manaje rial}

Berdasarkan temuan penelitian ini penulis memberikan beberapa rekomendasi yang menyangkut strategi pemasaran yang bisa dilakukan dengan perspektif jangka panjang, yaitu dengan aktivitas membangun merek (brandbuilding activity) dan aktivitas yang merusak merek (brand-harming activity) karena hal tersebut memegang peranan sangat penting untuk membangun mengkomunikasikan suatu produk ke masyarakat. Betapapun berkualitasnya suatu produk, bila konsumen belum pernah mendengarnya dan tidak yakin bahwa produk itu akan berguna bagi mereka, maka mereka tidak akan pernah membelinya (Tjiptono, 1998;35).

Pertama, mengenai harga yang digunakan sebagai alat positioning utama dalam membedakan suatu produk. Sesuai dengan konsep value pricing, menurunkan harga akan meningkatkan nilai suatu produk, menciptakan suatu persepsi hemat/saving (Dodds et al, 1991;63). Mengkombinasikan tingkat harga yang sama atau lebih tinggi dengan kemampuan produk yang berkualitas tinggi mungkin merupakan strategi yang lebih menarik dan sesuai dari perspektif ekuitas merek.

Kedua, distribusi secara intensif, karena membuat produk tersedia lebih banyak di toko akan memberikan kenyamanan, hemat waktu, jasa yang cepat, dan aksesibilitas yang pada akhirnya akan meningkatkan kepuasan pelanggan. Dis tribusi intensif ini sesuai untuk produk convenience.

Ketiga, iklan dalam iklim persaingan yang tajam semakin memegang peranan yang sangat besar. Oleh karena itu secara teratur dan terencana 
perusahaan harus mampu membangun dan meningkatkan citranya di pasar melalui iklan yang berkelanjutan dan secara spesifik harus dirancang sedemikian rupa sehingga bisa membangun kepedulian merek dan iklan, kualitas persepsi dan asosiasi merek yang tinggi sehingga akan masuk dan mengendap dalam consideration set konsumen. Tentu saja iklan tersebut harus dapat menarik perhatian audience dan jujur, sehingga iklan tersebut tidak hanya berhenti pada sekedar kenal dikenal, tetapi akan melekat dalam persepsi, sikap, dan perilaku mereka dan menjadi pengabai merek lain.

\section{Keterbatasan Penelitian}

Walaupun penelitian ini sudah dirancang dan dilakukan sebaik mungkin, tetapi penulis menyadari bahwa penelitian ini masih mempunyai beberapa keterbatasan, antara lain:

1. Penelitian ini menggunakan alat analisis $D E A$, yang mempunyai asumsi, yakni: a. DEA mensyaratkan input dan output yang harus dapat diukur, kesalahan dalam penentuan input dan output yang valid akan mengakibatkan hasil yang bias.

b. Bentuk dasar DEA berasumsikan adanya Constant Return of Scale (CRS) terutama dalam menentukan target input dan output, yang menyatakan bahwa perubahan proporsional pada semua tingkat input akan menghasilkan perubahan proporsional yang sama pula pada tingkat output, walaupun pada kenyataannya hal ini jarang terjadi.

c. Bobot input dan output yang dihasilkan $D E A$ tidak dapat ditafsirkan dalam nilai ekonomis sebab $D E A$ bertujuan mengukur efisiensi teknis relatif.

d. $D E A$ sangat cocok untuk menghitung efisiensi relatif, tetapi tidak dapat mengukur efisiensi secara absolut. Dengan kata lain, suatu unit analisa merupakan unit yang terbaik (100\%) hanya diantara sekumpulan unit yang diperbandingkan, bukan menyatakan unit yang secara mutlak terbaik menurut teori.

2. Penelitian mengenai ekuitas merek, penulis hanya membatasi pada efisiensi yang terfokus pada harga sebagai satu-satunya sumber ekuitas merek dan hanya melihat dari sisi tingkat efisiensinya saja. Sebenarnya banyak variabel 
pemasaran penting lain yang turut serta dalam menentukan besarnya ekuitas merek, seperti: strategi produk, saluran distribusi dan promosi.

3. Dalam menentukan responden, peneliti melakukan secara aksedental, sehingga sulit untuk mengidentifikasi responden yang efektif.

\section{KESIMPULAN DAN SARAN}

\section{Kesimpulan}

1. Dari tujuh merek minuman energi dalam kemasan botol kaca ukuran $150 \mathrm{ml}$ yang beredar di pasaran (Kratingdaeng, Hemaviton, Lipovitan Honey, Lipovitan Royal Jelly, Panther, M-150, dan Fit-UP) ternyata terdapat satu merek yang tidak efisien, yakni Kratingdaeng. Hal ini terjadi karena merek Kratingdaeng mempunyai harga jual yang lebih mahal dibandingkan merek lain padahal kandungan yang ada relatif sama dengan merek lainnya.

2. Kratingdaeng sebagai merek yang tidak efisien malah mendapatkan nilai ekuitas yang tinggi dibandingkan merek Panther yang dikatagorikan merek yang efisien, bahkan persepsi konsumen terhadap merek Panther negatif. Hal ini disebabkan keberhasilan Kratingdaeng dalam menciptakan image bagi mereknya sebagai merek yang berkualitas dijajaran merek minuman energi yang ada dengan menetapkan harga yang lebih mahal dibandingkan merek yang lain.

3. Merek dengan atribut yang hampir sama namun dengan tingkat efisiensi yang lebih tinggi akan menghasilkan kepedulian merek, asosiasi merek dan kualitas persepsi yang tinggi pula. Hal ini menunjukkan bahwa ekuitas merek bisa dikembangkan dengan meningkatkan kepedulian merek asosiasi merek, dan kualitas persepsi melalui suatu desain investasi pemasaran secara hati-hati. Sedangkan untuk kepedulian iklan tidak terpengaruh oleh tingkat efisiensi, karena dalam hal ini iklan hanya sebagai pengetahuan bagi mereka bukan untuk membujuk, maka itu untuk mendorong kekuatan suatu mere, manajer harus melakukan investasi dengan lebih tepat dalam periklanan 


\section{Saran}

Melihat keterbatasan yang ada maka untuk penelitian lebih lanjut disarankan untuk menambahkan jumlah dari jenis/merek minuman energi, tidak hanya terbatas pada kemasan dalam botol kaca ukuran $150 \mathrm{ml}$ saja. Selain itu dalam menentukan responden harus benar-benar selektif, sehingga hasilnya nanti akan lebih mewakili. Untuk meneliti unit analisa bisa menggunakan variable return to scale (VRS) terutama increasing return to scale (IRS) di mana ini lebih sering terjadi dalam praktek.

\section{DAFTAR PUSTAKA}

Aaker, D.A \& Keller, L.K,, (1990), Consumer Evaluation of Brand Extensions, Journal of Marketing, Vol.54, January

Baskoro, Yodho, ,(2002), Hubungan antara Unsur-Unsur Bauran Pemasarasn dengan Penciptaan Ekuitas Merek, Tesis, PPSUB, Malang

BPS, Kota Malang,, (2005), Malang dalam Angka, Pemkot, Malang

Codd, Walgen, ,(1995), Brand Equity, Brand Preference, and PurchaceIntent, Journal of Advertising, 24 (3),p.25-40

Cooper,W.W. ,(1999), IDEA and AR-IDEA:Models for Dealing with Imprecise Data in DEA, Journal Management Science, Vol.54,NO.4,April, P.597606

Dodds, William, ,(1991), Effects of Price, Brand, and Store Information on Buyer Product Evaluation, Journal of Marketing Research, 28, August, p.307319

Indocommercial, ,(1998), Laporan Khusus Profil Bisnis, No.201, Mei

Keller, K.L, ,(1993), Conceptualizing, Measuring, and Managing Customer Based Brand Equity, Journal of Marketing, Vol.57, January

(1998), Strategic Brand Management Building, Measuring and Managing Brand Equity, 1 st ed New Jersey, Prentice Hall Inc.

Kotler, Philip, .(1997). Management: Analysis, Planning, and Control, 9 th ed, Prentice Hall. Inc.

Loudon, D.L and Dell, Bitta. (1993). Consumer Behavior, Concept and Applications, 4 th ed, New York 
Mowen, Jhon.C..(1998). Consumer Behavior, fifth ed, New Jersey, Prentice Hall, Inc.

Nugroho,S.S., .(1995). Analisis DEA dan Pengukuran Efisiensi Merek, Jurnal Kelola, No.8/IV, Yogyakarta

Solimun,DR, dan Ani,B.A. (2001). Statistika Non-Parametrik, Penataran Penelitian dan Statistik Bagi Dosen Kopertis Wil.VII, BALPEKES Mrrnajati, Lawang

Tjiptono, Fandy. (1998). Strategi Pemasaran, Andi, Yogyakarta

*) Irmayanti Hasan, MM., Dosen Fakultas Ekonomi UIN Malang 